\title{
The Effect of Information Technology on the Bank Profitability Empirical Study of Jordanian Banks
}

\author{
Sahem A. Nawafleh ${ }^{1}$ \\ ${ }^{1}$ Department of E-business, University of Petra, Jordan \\ Correspondence: Sahem A Nawafleh, Department of E-business, University of Petra, Jordan. E-mail: \\ Snawafleh@uop.edu.jo
}

Received: October 30, 2014

Accepted: December 16, 2014

Online Published: January 20, 2015

doi:10.5539/ijbm.v10n2p170

URL: http://dx.doi.org/10.5539/ijbm.v10n2p170

\begin{abstract}
This study examines the impact of information technology on banks' profitability. The data were collected through two type questionnaires distributed at the clients and banks' staff. The data were analyzes using SPSS test, Averages and Standard Deviations test, Tree Cluster Analysis, and T-test for one sample. The study found that demographical characteristics affect affects the obstacles of using E-banking, and the capital of the commercial banks has a significant impact over their expansion.
\end{abstract}

Keywords: information technologies, profitability, e-banking

\section{Introduction}

The banking and financial developments witnessed by the global arena in the last few decades represents a response to the evolution of this structure; and in the forefront of these developments are Trade and investment liberalization, currency exchange rates floating, the removal of barriers to the movement of capital flows to and from the financial and banking markets, competition aggravation, emergence of the massive banking entities through bank's mergers, rapid developments witnessed by the Information and Communication Technology the expansion of electronic banking tools to promoting banking products which in turn reflected positively on improving the banking service's quantity and quality, and increasing competition between banks (European central bank, 2004).

However, the competition has become more difficult as a result of the rapid changes brought about by the ongoing advances in technology and other global developments related to banks' activities, which will lead to increased competition in the banking industry and its expansion to become competitive on a wide-open global market.

The banks, as a result of the sharp fluctuations in the wholesale operations, expanded toward the broad base of their retail customers who full of profitability opportunities. If the infrastructure of hardware, software and other integrated, the wheel of progress in this area will continue in order to achieve integration in the relationship with customers using various channels, through all hours of the day, including regular branches, remote financial services, telephone, ATM, the Internet and personal computers and then re-designing the banks in order to achieve that. The developing countries, including Arabs, have insignificant contribution on the scientific and global technological production level. They still are receiving these developments through its open markets and their needs for it. In addition, these countries are not immune to the effects of these global developments. There are many indicators that emphasize widen of a scientific and technological gap between developed and developing countries; in the banking field, the gap still exists with respect to information technology, particularly to items and zones of electronic banking which are the subject of this study (Thomas L, \& David Hunger, 2012).

\subsection{The Study Problem}

The scientific and technological development witnessed in the banking arena, and the resulting widespread use of the tools and electronic banking channels in developed countries which exceeds in terms of quantity and quality that seen in developing countries, requires studying and analyzing the causes and obstacles to the expansion of e-banking in Jordan. As this expansion is linked to the main parties accountable for it and represented in banks and their customers, the problem of the study is shown through defining the responsibilities of these parties (The Global Information Technology Report 2009-2010). 
First: Central Bank as a representative of the monetary authority, the regulator of the banking sector, responsible for legislation, regulations, monetary and banking policies which contribute in providing the banking environment that banks operate within its scope, thus affecting the size and quality of e-banking Second: Banks as being considered the responsible party for providing quantitative and qualitative Electronic Banking Tools which requires knowledge of the importance of each of the organizational factor, financial, behavioral, environmental, and other factors associated with the application of information technology. One of its important components is the Electronic Banking Tools; due to their impact on banks' profitability and market share.

Third: Individuals as dealers with the Electronic Banking Tools and trying to determine the extent of their habits and banking behavior progress and awareness with regard to broaden the use of E-banking base.

The interest in identifying the three parties' basic responsibilities could lead to identify the subjective and objective factors influencing the broadening of E-banking usage base by diagnosing these factors and foreseeing the future prospects for E- usage in Jordan

\subsection{Hypotheses of the Study}

There is a statistically significant relationship between constraints of technology use and demographic characteristics of the clients.

There is a statistically significant relationship between the commercial bank's capital size and its ability to expand the tools of technology due to its impact on the bank profitability its market share.

\subsection{Limitation of the Study}

The inability to obtain detailed data (By the central bank or the Association of Banks), with regard to the volume of E-banking use in terms of E-channels used and the number of users for each bank individually.

The inability to obtain detailed data from the Jordanian Commercial Banks, with regard to the volume of E-banking usage, both in terms of E-channels used, or number of users per Bank.

\section{Theoretical Background and Literature Review}

A chief progress in the economic and societal arenas has been witnessed in Jordan within the earlier years. The advancement of the banking system is of the utmost significant aspects of economic advancement in Jordan.

\subsection{ATMs' in Jordan}

ATMs have been used in Jordan at the beginning of the eighties of the last century, and today they and points of selling are spread in all regions of the Kingdom and in the branches of global banks and major commercial centers, hospitals and universities; making it easier to handle and reduces dependence on exchange dealings. ATMs' machines reached to 846 machines in the country at the end of 2007(Laith Talal Khrais, 2012).

\subsection{Proliferation Channels and Electronic Services in Jordanian Banks}

Eight electronic channels, In addition to the prevalence of ATM, were adopted as the most important electronic channel currently exists. This is related to the fact that branches are the most important resources of publicity and advertising for Electronic Channels. Branches including the largest percentage of ATMs can be seen as follows (Vrontis \& Thrassou, 2013).

- The significant differences in the spreading size of ATMs as one of the most important electronic channel between Jordanian banks, Where the customer can get several banking services;

- The significant differences in the spreading size of E-channels, for instance, of eighteen Jordanian commercial banks; E-Bank is only delivered by three banks. In additions, Customer Service provides an integrated manner through one bank obtained from the rest channels, whether it is an inquiry service or executive service to the account. While in the other banks customer can get some information regarding the Bank's services only without getting any information regarding their account or carry out financial operation on the account;

- There are only three banks having seven electronic channels out of eight electronic channels, As well as having good branches and ATMs' machines spread. These banks are: housing, Arab, Jordanian and Kuwaiti.

- The E-channels such as Spoken Bank possessed by twelve commercial banks is maintained by eleven banks. Nonetheless, the main variances in the size of the services obtained over these channels amongst the banks that possess such channels is what noted;

- The declined number of E-Channels, and the important variances amid Jordanian banks in the total of electronic channels they possess. 


\subsection{Literature Review}

Kolodinsky, Jane and Hogarth Jeanne (2004) study investigated factors that influence American Banks customers' embracing of the technology of e-banking. This study aims ATM, Internet banks, money transfer and electronic payment. The study reached that demographic variables play a noteworthy role in client adoption of this technology. Yet, there is difficulty in dealing with electronic banking technology by the elderly and law certificates holders. The study recommended that banks to encourage customers to adopt the e-banking technology through endorsing the welfares gained as saving time and effort. Likewise, the study indorsed those banks to implement a strategy that ends to improved consumer confidence in electronic banking technology with respect to the accessibility and security.

Al-Jamal, Refah (2006) aimed to identify the authenticity of the spoken bank services' quality of Arab Bank, and the influence of personal factors in evaluating the provided services quality. The study found that customers have a high impression about spoken bank services quality and that the difference in assessing the services quality, provided by the spoken bank, attributed to the personal variables.

Kolodinsky, Jeanne (2004) lead a study in the aspects prompting customers' implementation of the four categories of electronic banking technology, specifically: Spoken Bank, Internet Bank, electronic payments' means, and electronic transfer of funds' approaches. The study ends that male's desire to practice electronic banking, along with electronic payment approaches, whereas, females choose using Spoken Bank. Besides, there is a substantial in practice scope with respect to demographical variables, such as: Income had an important effect; those of high wages have been intensifying their access of E-banking. Whereas gender, marital status, or education level have no impact on the E-banking expansion. In addition the study also highlighted the most important obstacles that prevent E-banking use like: the difficulty electronic channels usage procedures, and knowledge lack of the benefits that clients gain through the use of those channels for various banking services.

Casolaro, Gobbi (2004) study, on more than 600 Italian Bank, aimed to identify the impact of information technology usage expansion on E-Banking in Italian Banks. The study showed a significant effect for the expansion of information technology use on the coast, profitability and productivity in Italian banks.

Mcphail, Fogarty, Gerard (2004) study conducted on Australian bank customers, where the study aimed to identify the demographic variables for the customers and the use size of IT self-service banking of those customers. The study focused on the four E-channels which are: ATM, Spoken Bank, Internet Banks, and POS. the study found that The older the client, the less convictions in using new electronic channel, especially for the Spoken Bank; the age factor was found to have more impact than other factors, such as academic achievement and income. The study suggested that to focus on the privileges of using E-channels in saving time and effort, in addition, it is necessary to study the cultural and social factors of the environment surrounding the customer.

Anguelov, Hilgert and Hogarth (2004) study that was lead on the American Banks' clients intended to attest that the growth and reception of electronic banking technology practice such as: ATMs, Internet Bank, and electronic payment means relays on the consumer characteristics and features as demographic variables; age, income, and other. The study revealed that E-Banking products are used by those of high-income, high financial resources, youth groups, and individuals with advanced educational accomplishment. The study resolved that the main vital impediment in respect to the Service is the lack of privacy and security, and ease of use. The study endorsed that the American Federal Bank to issue Depositary Receipts to be electronically subscribed.

\section{Methodology}

\subsection{Study Sample}

The Study Sample includes all clients who have checking and saving accounts in the period between 1/5/2009 $15 / 5 / 2009$ at the Jordanian commercial banks, which included (18) according to the study. The study sample consisted of all general managers and their assistants, departments' managers, branch managers, and heads of departments in these banks. The study only adopted the local banks in the final evaluation of Banks according to E-banking and excluded the foreign banks in Jordan.

\subsection{The Study Tool}

In order to achieve the objectives of the study, a questionnaire was designed specially to address the study questions and hypotheses. The questionnaire was divided into two parts; the first part contains general information related to the study sample demographic and functional characteristics. While the second part includes questions that measure the reality of e-banking in Jordan in terms of the type of employed channels, the obstacles that prevent the use of e-banking, the ways to identify the advertised e-banking services and economic feasibility of using electronic banking. 


\subsection{Validity of Study Tools}

In order to check the validity of the study tool, it has been presented to a group of arbitrators and specialists in the Banking and Finance fields. Their observations were used in the construction of the scale.

\subsection{The Stability of the Tool (Reliability)}

In order to check the stability of the tool, the measure has been applied on a sample of (30) of clients who meet the characteristics of study sample and the reliability factor of internal consistency calculation By Alfa Akron Bag Factor. The total reliability factor was (0.88) and this is an indication that the resolution has connotations of stability and meets the objectives of the current study.

\subsection{Data Sources}

The study relayed on two types of data sources; (1) through reviewing the sources that dealt with E-banking, and reviewing previous studies that dealt with the issue of E-banking on the local, Arab, and foreign level. (2) The data were collected in the field through the application of study measures on the study sample that represents the original community, and which included two parts: geographic information and questions measure E-Banking in Jordanian banks.

\subsection{Data Analysis}

SPSS test used, in addition to the following:

-Averages and standard deviations;

-Tree Cluster Analysis;

-T-test for one sample.

\section{Discussion}

A two type questionnaires were distributed to analyze the hypotheses of the study. The first questionnaire was addressed to clients of Jordanian banks maintaining accounts with banks under study to examine the first hypothesis. It was made up of a number of questions designed to identify the obstacles that hinder the expansion of E-banking by customers, (70) questionnaire was distributed; (62) questionnaires were recovered, thus the ratio of recovery was (88.5\%).

The second questionnaire was addressed to the departments of commercial banks to examine the second hypothesis. The questionnaire was distributed those concerned with the rank of general director , Department director, Branch Manager, and Head of the Department, in the centers and branches of banks included in the study; (40) questionnaires were distributed on the banks' branches, where (36) of them were recovered. Thus the ratio of recovery was (90\%).

\subsection{Customers' Reasons for not Getting E-Cards}

The reasons for lack of access to e-card from the viewpoint of respondents who do not have the cards as follows: the account balance is slight, the branch being near the work of house, the account is only the salary that is withdrawal at the end of the month, the lack of conviction of these cards, and the desire to deal directly with the branch, and the inability of some customers to get the e-card because they are illiterate and bank's instructions do not allow them to get the card.

Analyzing the collected data in regard with second questionnaire, the following was shown:

a. There is significant weakness in the size what Jordanian banks own of E-channels, and weakness of the number of services offered by these channels.

b. There are only three banks got a degree equivalent to (50\%) or more; these banks are the Arab Bank, the Housing Bank, Jordan Kuwait Bank.

c. With regards to the assumption that banks that have large capital, expand into electronic banking; Pearson Correlation factor was calculated between the bank's capital and the degree to which the bank achieved in E-banking. The correlation factor was (0.76), and it is at the statistical significance level of (0.01) or less.

\section{Results and Recommendations}

\subsection{Results}

1) With regard to the relationship between demographic variables for customers and the sense of obstacle's degree, it has been found that increased income increases the sense of obstacles. As well as for age; getting older increases sense of obstacles. While the relationship between gender and sense of obstacles is less relevant. This 
proves the first hypothesis, which assumes that there is a statistically significant relationship between the obstacles of using e-banking and demographic characteristics of the clients.

2) There was a statistically significant relation between sex and age variables on one hand, and between increased the sense of obstacles on the other hand. As well as between income and age variables on one hand, and between increased the sense of obstacles, conversely; It has been shown that people whose age between (36-45 years) and their incomes are more than (1000 JD); females sense obstacles more than males. While people whose age between (36-45) years, and their income is between (150-300 JD); the males sense obstacles more than females. This proves the first hypothesis, which assumes that there is a statistically significant relationship between the obstacles of using e-banking and demographic characteristics of the clients.

3) With regard to the Jordanian banks order depending on the level of the expansion of e-banking and the bank's capital, the following has been found:

a. There is significant weakness in the size what Jordanian banks own of E-channels, and weakness of the number of services offered by these channels

b. There are only three banks got a degree equivalent to (50\%) or more; these banks are the Arab Bank, the Housing Bank, Jordan Kuwait Bank

c. With regards to the assumption that banks that have large capital, expand in electronic banking; Pearson Correlation factor was calculated between the bank's capital and the degree to which the bank achieved in E-banking. The correlation factor was (0.76), and it is at the statistical significance level of (0.01) or less. This proves the second hypothesis which assumes that there is a statistically significant relationship between the size of the commercial bank's capital and its ability to expand in E-banking.

\subsection{Recommendations}

\subsubsection{Recommendations Related to Customers}

a) Marketing campaign aimed at increasing awareness among banking customers with E-channels and services provided through it. Through this marketing campaign, which must be periodically, customers are introduced to the features and benefits they receive through their use to the service over these E-channels like saving time, effort, fees and other.

b) Up keeping campaign to E-cards promoting, Along with, the ATM card, as the bank ought to advertise further E-cards such as Visa card, MasterCard, on-line shopping cards, and other cards that boost customers to employ such electronic channels. It is imperative that commercial banks to perform procedures in order to facilitate customers get those cards such as exempting the client of card issuance commission for the first-year.

c) Through those marketing campaigns undertaken by commercial banks, confidentiality and security must be provided for customers who use E-channels and to avoid adding any kind of charges to clients like the imposition of novel charges as it will practice a barrier limiting the expansion of customers employing E-banking.

d) It is important to acknowledge and understand of the obstacles that prevent the expansion of E-banking customers, as well as the study of the client's current and future needs, listening to their problems and suggestions in this regard. That can be achieved by commercial banks through carrying out studies on this topic periodically and by trained and qualified staff targets to encourage customers to employ electronic channels. Aimed at the same purpose, it is essential to investigate several free services that clients can attain over these E-channels, even for a limited period, additionally to the central bank to support these studies conducted by banks.

e) Divisions of commercial banks need to encourage customers to practice additional of the E-channels services, by logging into a number of accessible and inactive services, likewise, depositing cash and checks through ATM and payments' settlement via the Internet and further channels. It is required to motivate the role of the branches and bank's sales team and afford them with satisfactory expertise, along with, activating the role of the publicity approaches such as newspapers, TV's, and other media; where there are vast sums of cash paid on these means without reaching the preferred goals in marketing channels and E-services and the expansion of banking awareness as it will transfer in the concern of banks and clients.

\subsubsection{Recommendations Related to Commercial Banks}

a) Banks must foster the culture of electronic banking at senior management, not only among specialized staff, and to state its significance and benefits in increasing profits, increasing competitiveness, increasing marketing area, bank's progress and continuity, and eliminating doubts amid staff about their awareness that the 
implementation of these innovative technology results in dispense them.

b) Provide the most advanced available hardware and software, which must be obtained for E-banking expansion, increasing the number of used ATMs and other E-channels to facilitate the procedures of using these channels for different services.

c) Banks obligated to retain pace with new technological banking improvements in relation to adding new channels or evolving already existed channels by increasing the number of facilities delivered by these channels.

d) delivering training sessions, internal and external, periodically for all concern staff so as to make them alert of the prominence of E-banking expansion, in addition to their understanding of what is presently applied in the bank, and make them aware of what is brand new in the arena of E-banking so as to offer a skilled and competent staff.

e) The use of specialized advertising institutions specialized in marketing and training concerned staff in the bank.

f) Create a specialized administrative responsible for supervising these channels, developing them, providing protection and confidentiality for the applied system, and processing errors and malfunctions.

g) Banks need to offer material and honorable incentives for their staff to boost the marketing of E-channels, along with the necessity to afford time for marketing those channels and E-services over several marketing channels, mainly branches.

h) Departments of banks need to adopt a marketing and promotional policy for available E-channels by involving these banks' staff in this policy after providing the required accessories like time managements and granting incentives to these workers.

i) The study showed that there is a strong relationship amid the capital size and the bank's ability to increase technology tools. Consequently, there is a need at several Jordanian banks to promote their capital so as to increase its ability to expand in E-banking.

\section{References}

Casolaro, L., \& Gobbi, G. (2007). Impact of information technology and productivity changes in the banking industry economic notes.

McPhail, J., \& Fogarty, G. (2004). Mature Australian consumers' adoption and consumption of self-service banking technologies. Journal of Financial Services Marketing, 8(4), 302-313.

Anguelov, C., Hilgert, M., \& Hogarth, J. (2004). US Consumers and Electronic Banking: 1995-2003. Federal Reserve Bulletin, 90(1), 13-16.

Jeanne, M. H., \& Marianne, A. H. (2004). The adoption of electronic banking technologies by US consumers. The International Journal of Bank Marketing, 22(4), 238-259.

Thomas, L., Wheelen, J., \& David, H. (2012). Strategic Management and Business Policy, toward global sustainability.

Demetris, V., \& Alkis, T. (2013). Innovative Business Practices: Prevailing a Turbulent Era, Cambridge Scholars Publishing. 12 Back Chapman Street, Newcastle upon Tyne.

Laith, T. K. (2012). The Adoption of Online Banking: a Jordanian Perspective. European Journal of Business and Management, 4(16).

\section{Copyrights}

Copyright for this article is retained by the author(s), with first publication rights granted to the journal.

This is an open-access article distributed under the terms and conditions of the Creative Commons Attribution license (http://creativecommons.org/licenses/by/3.0/). 